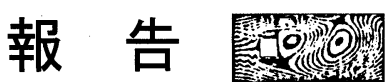

\section{6 年台風 13 号に伴って発生した竜巻による延岡市の被害調査速報 \\ Preliminary report on damage in Nobeoka City due to tornado accompanying typhoon Shanshan (T0613)}

On September 17, 2006 serious damage had been caused by tornado accompanying Typhoon Shanshan (T0613) at Nobeoka City, Miyazaki Prefecture. Due to the gust the first and the second cars of a limited express train cars were overturned. More than a thousand houses were damaged. Three people were killed. The notable feature of this wind damage was impact of wind borne debris. The estimated damage scale was F2 and the maximum gust speed of $46 \mathrm{~m} / \mathrm{s}$ was observed at a factory yard. The area of damage footprint was spread to $7.5 \mathrm{~km}$ from Pacific coast to the north-east by $100 \mathrm{~m}$ to $200 \mathrm{~m}$ in width. Results of the site investigations were reported.

Keyword: Tornado, Flying objects, Typhoon, Damage, Derailment

$$
\text { 宮城弘守*1 菊川裕規*2 松井正宏*3 }
$$

Hiromori Miyagi, Hironori Kikugawa, Masahiro Matsui 曹 曙陽 ${ }_{4}$ 田村幸雄 ${ }^{* 5}$

Shuyang Cao, Yukio Tamura

\section{1. はじめに}

2006 年 9 月 10 日にフィリピン東海沖で発生した台 風 13 号(国際名 Shanshan)は, 発達しながら北西に進 み，15 日から北寄りに向きを変えて 16 日には石垣島 付近を通過し，東シナ海を北上して 17 日には九州に 接近した。17 日 18 時過ぎに長崎県佐世保市付近に上 陸し, 佐賀県, 福岡県を通過して 20 時頃に玄海灘に 抜け, 日本海を北上して 9 月 20 日に北海道に再上陸 し, 温帯性低気圧に変わった。

この台風 13 号が九州に上陸する少し前の 9 月 17 日 14 時頃, 宮崎県延岡市で突風被害が発生した。被害は, 死者 3 人,住家, 非住家あわせて全壊 94 棟等におよび, 日豊本線では特急「にちりん」が横転した。現地の被 害状況, 被害者からの聞き取り調査により宮崎地方気 象台はこの突風の原因を竜巻によるものと判断した。
この竜巻による被害の現地調查を被害発生翌日 9 月 18 日から実施した。その結果, 延岡市の市街地をほぼ 南北に縦断する形で被害が分布していることが明らか となった。また, 被害復旧活動が落ち着くのを待って, 延岡市役所への聞き取り調查を 11 月 7 日に実施した。 以上の調查結果について報告する。

\section{2. 被害統計}

延岡市役所による人的被害・住家被害の状況を表 1 に示す。延岡市は, 被害発生直後から 24 日までに 1 次, 2 次調查を実施し, 屋根の破損面積, 主要構造骨 組の損傷状況等に基づき,建物の被害状況を判定した。 また，被災者生活再建支援制度など公的援助の基準に なる全半壊の区分については, 29 日に判定会議を開き, その後, 調査した全世帯に通知した。

*1 宮崎大学工学部 助手, Assistant, Miyazaki University,

*2 大分工業高等専門学校 助教授, Associate Professor, Oita National College of Technology,

*3 東京工芸大学工学部 助教授, Associate Professor, Tokyo Polytechnic University,

*4 東京工芸大学工学研究科 COE 助教授, COE Associate Professor, Tokyo Polytechnic University,

*5 東京工芸大学工学部 教授, Professor, Tokyo Polytechnic University 
表 12006 年 9 月 17 日 延岡市の竜巻による被害統計 (延岡市防災推准室調心 : 2006 年 11 月 6 日現在, 旭化成除く)

\begin{tabular}{c|c|c|c|c|c}
\hline \hline 人的被害 & \multicolumn{2}{|c|}{ 死者 } & \multicolumn{2}{|c|}{ 重傷者 } & \multicolumn{2}{c}{ 軽傷者 } \\
\hline (人) & \multicolumn{2}{|c|}{3} & \multicolumn{2}{|c|}{3} & \multicolumn{1}{c}{140} \\
\hline \hline 住家被害 & 全壊 & 大規模半壊 & 半壊 & 一部破壊 \\
\hline (棟) & 79 & 83 & 265 & 753 \\
\hline \hline 非住家被害 & 全壊 & 大規模半壊 & 半壊 & 一部破壊 \\
\hline (棟) & 15 & 9 & 33 & 110 \\
\hline \hline 被害額 & 水産 & 農業 & 商工 & $\begin{array}{c}\text { 公共 } \\
\text { 施設 }\end{array}$ & 合計 \\
\hline (千円) & 65 & 88,474 & $1,188,700$ & 16,847 & $1,294,086$ \\
\hline
\end{tabular}

人的被害では 3 名が亡くなり, 11 月 7 日の佐呂間竜 巻による労災被害発生までの短期間であったが, 1971 年以降の気象庁の被害統計で死者数を更新する悲しい 記録となった。報道等によると, 浜町で 2 名(店舗陳列 棚の下敷, 屋外(畑)で高齢者がショック死), 山下町で 1 名(屋内に飛び込んできた飛散物が頭部を直撃)が亡 くなっていて, 屋内にいても飛来物による被害を受け る可能性があることが明らかとなった。

\section{3. 気象状況, 気象データ}

図 1 3 317 日 15 時の地上天気図, 14 時の衛星画 像, レーダーエコー図を示す。レーダーエコー図には 台風中心位置と移動速度を併記した。竜巻が発生した 9 月 17 日 14 時に台風中心は延岡市の西南西 約 $280 \mathrm{~km}$ に位置していた。竜巻発生当時, 延岡市は, 台 風中心から伸びるレインバンドの下にあった。今回の 竜巻はこのレインバンドを構成している積乱雲によっ てもたらされたと考えられる。また, 同様のレインバ ンドが南側にも伸びている。延岡市以外でも, 日向市, 日南市等で竜巻によるみられる突風被害が生じている が, これらの突風はこのレインバンド内で生じたもの と考えられる。このレインバンドが宮崎県上空を北上 して延岡市に達する約 2 時間の間に, 日南市・宮崎市・ 日向市で竜巻を含む突風被害が次々と発生した。詳し い検討が必要だが，宮崎県内を北上中のレインバンド は, 5 ケ所の被災地合計で約 15 分間, 海上や地上に突 風現象を生じさせている。

被害が細長い帯状で, 被害の方向に収束性が認めら れることから宮崎地方気象台では，今回の突風は竜巻 によるものであると 9 月 19 日に発表した。また，日 南市油津で 1 人，日向市幸脇・平岩で 7 人が負傷した

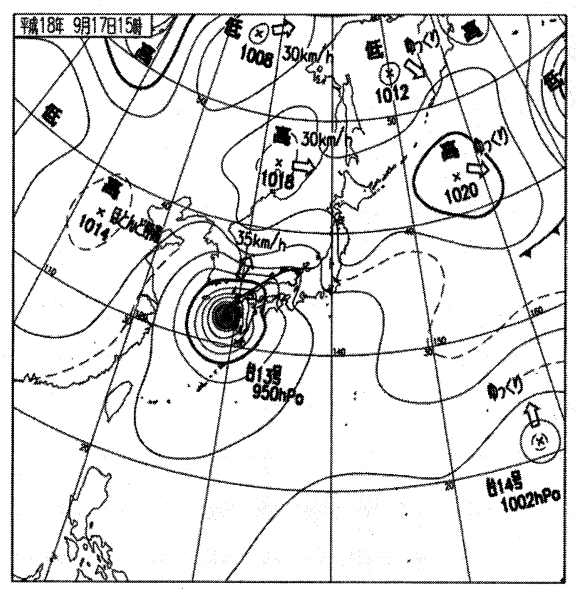

図 1 地上天気図 2006 年 9 月 17 日 15 時（気象庁）

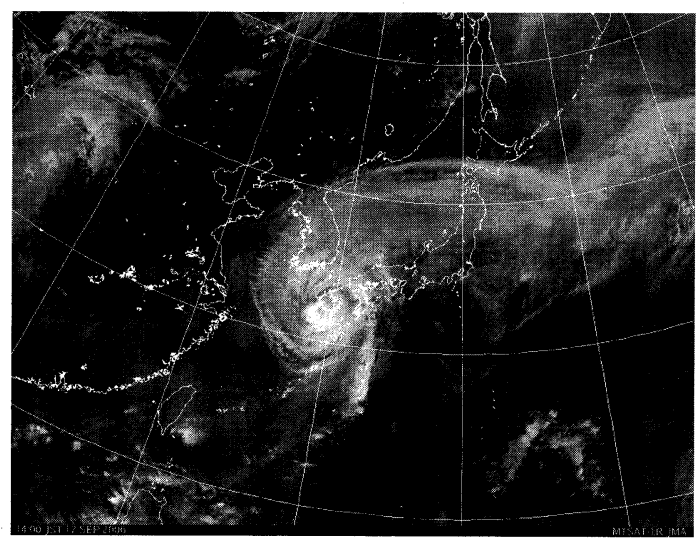

図 2 衛星画像 2006 年 9 月 17 日 14 時（気象庁）

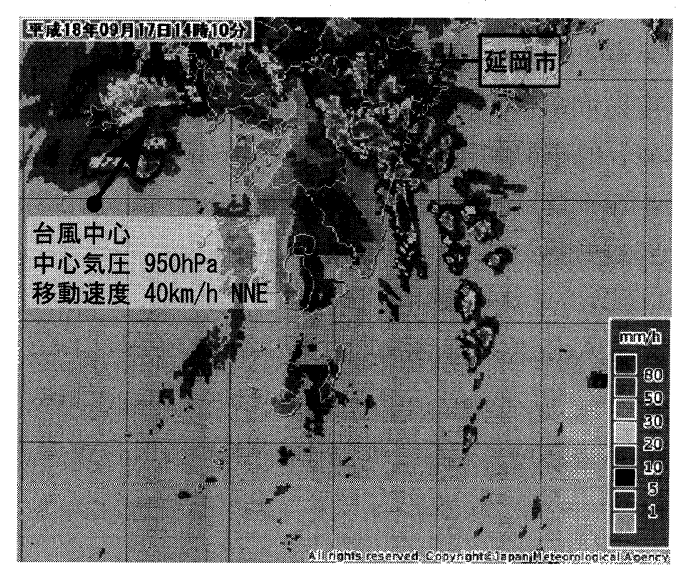

図 3 レーダーエコー 2006 年 9 月 17 日 14 時 10 分 (気象庁発表のものに台風中心位置等を加筆) 

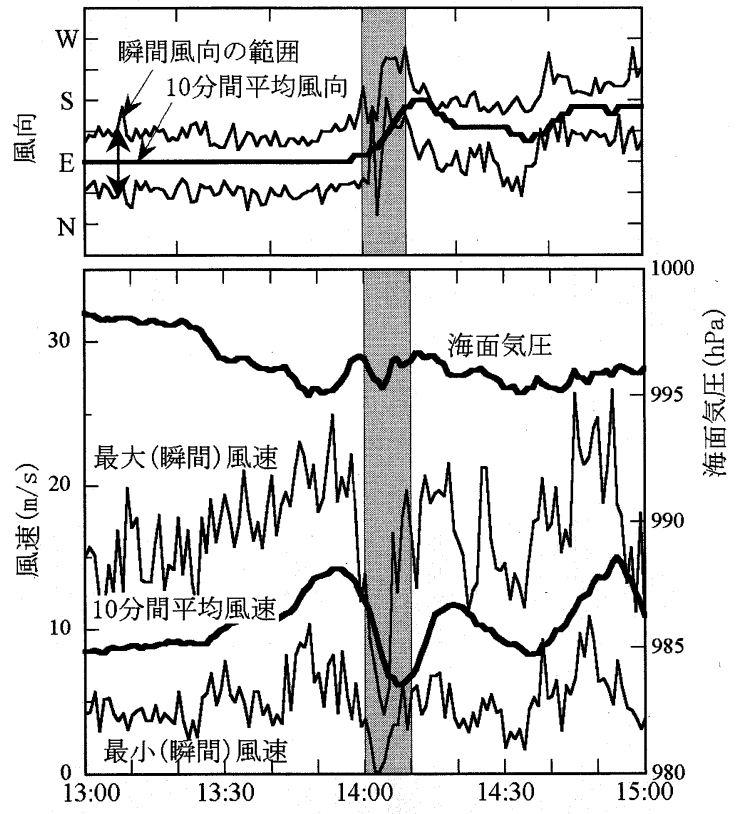

図 4 延岡特別地域気象観測所の風向, 風速の時刻歴

(気象庁, 1 分值)

表 2 風速観測記録

\begin{tabular}{l}
\hline 九州旅客鉄道株式会社 \\
五ケ瀬川橋梁 $14: 05$ 風速 $38 \sim 40 \mathrm{~m} / \mathrm{s}$ \\
(脱線事故現場から北 $1770 \mathrm{~m}$ 地点, 複数の報道による) \\
\hline 旭化成株式会社 \\
恒富地区 $14: 06$ 最大瞬間風速 $46 \mathrm{~m} / \mathrm{s}$ \\
\hline 愛宕地区 $14: 06$ 最大風速 $46 \mathrm{~m} / \mathrm{s}($ 注 $)$ \\
\hline \hline 延岡特別地域気象観測所
\end{tabular}

最大風速 $\quad 15.7 \mathrm{~m} / \mathrm{s} \mathrm{SSE} 17$ 日 18 時 50 分

最大瞬間風速 $34.0 \mathrm{~m} / \mathrm{s} \mathrm{SSE} 17$ 日 19 時 00 分

（注）記録された最大值。竜巻通過後, 風速計が破損していた。 破損原因は飛来物によるものと推定される。

突風についても宮崎地方気象台は, 現地調查の結果か ら,いずれも竜巻によるものと 9 月 22 日に発表した。 さらに 9 月 27 日の宮崎地方気象台発表による竜巻の 強度の推定結果は, 延岡市が F2, 日向市幸脇と日南市 油津がいずれも F1 である。

図 4 に延岡特別地域気象観測所における風向・風速 の記録を示す。竜巻被害が発生した 14 時から 14 時 10 分にかけてを網かけで示した。観測所は, 被害帯か ら $1 \mathrm{~km}$ 西側に離れているため, 竜巻による顕著な強 風が記録されていない。ただし，竜巻が反時計回りに
回転しながらほぼ北進したことから, 風速が弱まった 可能性がある。被害帯に近い観測記録を表 2 に示す。 被害地域から東に約 $300 \mathrm{~m}$ 離れた JR 九州の五ケ瀬川 橋梁(脱線事故現場から北 2 キロ地点)では, 14:05に約 $40 \mathrm{~m} / \mathrm{s}$ を観測した。また, 敷地内を竜巻が通過した旭 化成工場でも，2 ケ所で風の観測が行なわれていた。 1 ケ所は被害帯の中央にあって飛散物により破損したが，

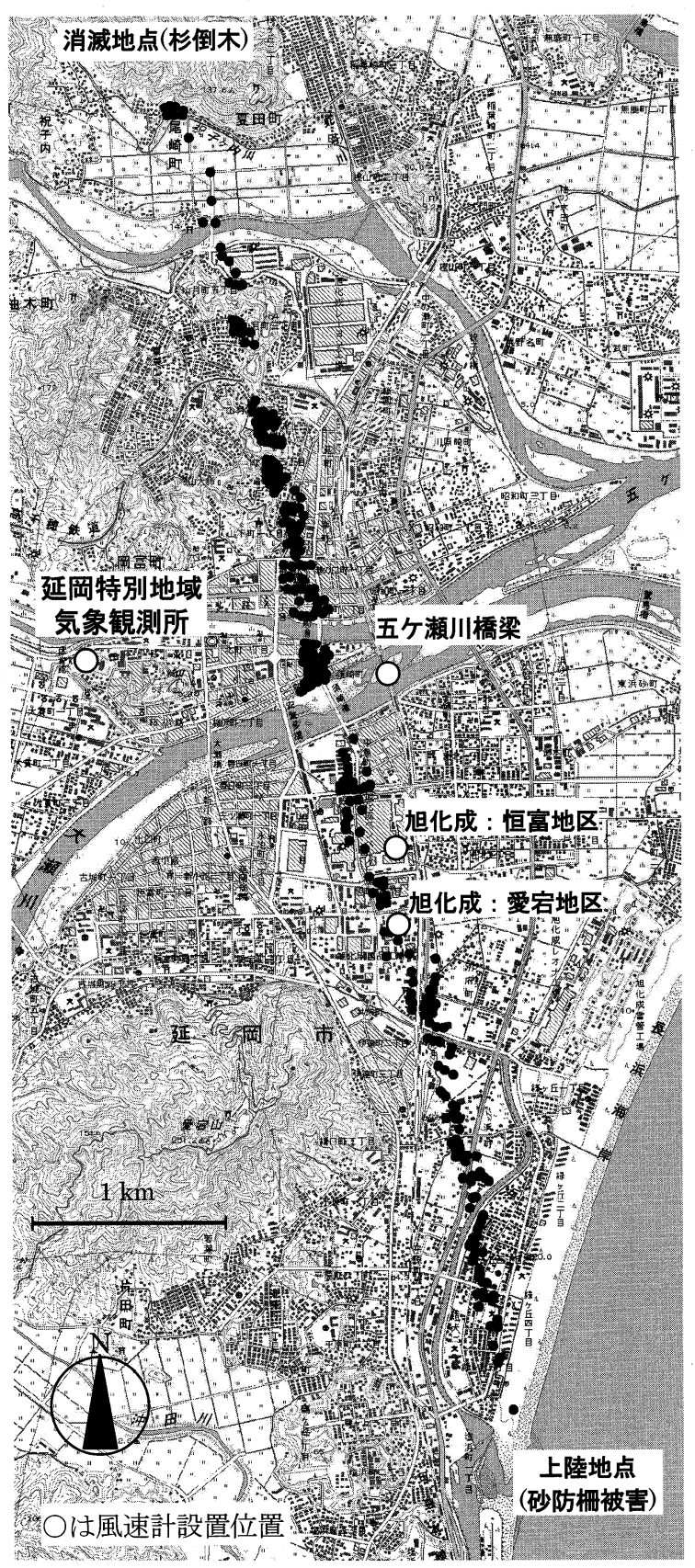

図 5 現地調査による地上構造物等の被害分布

(宮城, 菊川, 松井の 9 月 18 日, 19 日の調查結果に基づく) 
被害帯から東に 100〜 150m離れた 1 ケ所では破損が なく設置状況も良いことから，信頼できる。それによ ると，14:06に $46 \mathrm{~m} / \mathrm{s}$ が記録されており，今回の竜巻 による最大の突風は，少なくともこの風速を超えるも のであったと考えられる。この地点は, 竜巻の被害带 の東側であり, 突風被害の状況から竜巻の回転方向が 反時計回りであったと考えられるので，竜巻の進行方 向成分により強まる可能性のある領域であったとも考 えられる。

\section{4. 突風被害の概要}

\section{1 被害の分布}

図 5 に現地調查の結果，構造物等に被害が認められ た地点の分布を示す。被害は，延岡市緑ヶ丘 5 丁目の 海岸から尾崎町まで達寸る直線距離約 $7.5 \mathrm{~km}$, 幅 100 ～200m の範囲に分布していることが明らかとなった。

竜巻は延岡市緑ヶ丘の海岸から上陸したと考えられ る。また，上陸地点の南東約 $4 \mathrm{k} \mathrm{m}$ の遠見半島に竜巻 と見られる被害はなく，半島までの海上で発生したと 推定される。

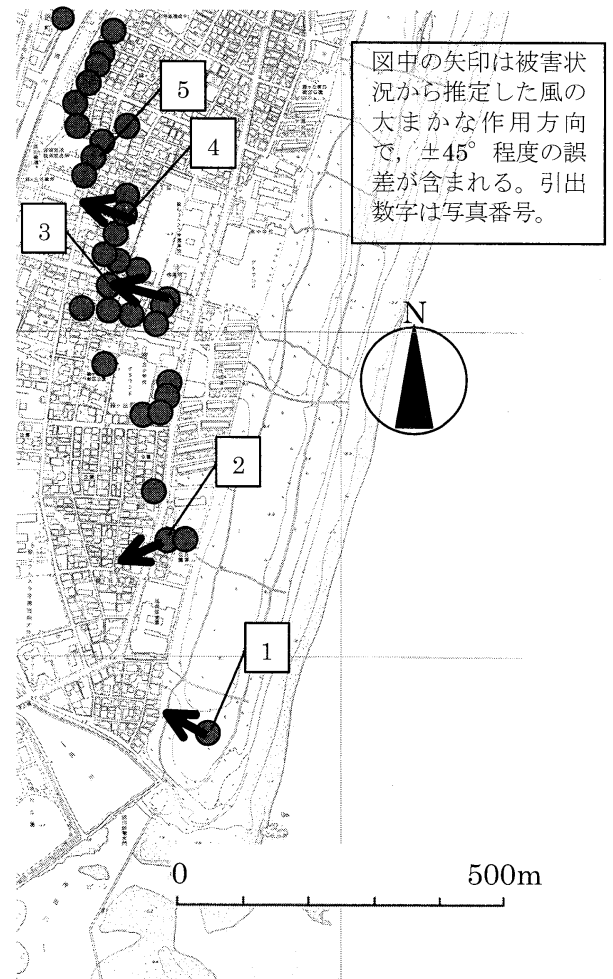

図 6 竜巻上陸地点, 緑ケ丘付近の被害

\section{2 竜巻上陸地点から国道 10 号線付近の被害}

竜巻が上陸したと考えられる緑ヶ丘 5 丁目の海岸で は，木製防砂柵が写真 1 の様にそこだけ $10 \mathrm{~m}$ 程度北 西に倒壊した跡があり，海上で発生した竜巻がこの地 点から上陸したと考えられる。

写真 2 に緑ヶ丘第一児童公園付近の被害を示す。北 西角に向かって樹木や電柱が傾き，北西角付近の建物 等に大きな被害が集中した。4 階建て集合住宅の後ろ の駐車場では，移動した自動車や横転したジープがあ った。竜巻の進行方向は写真中央奥向きである。

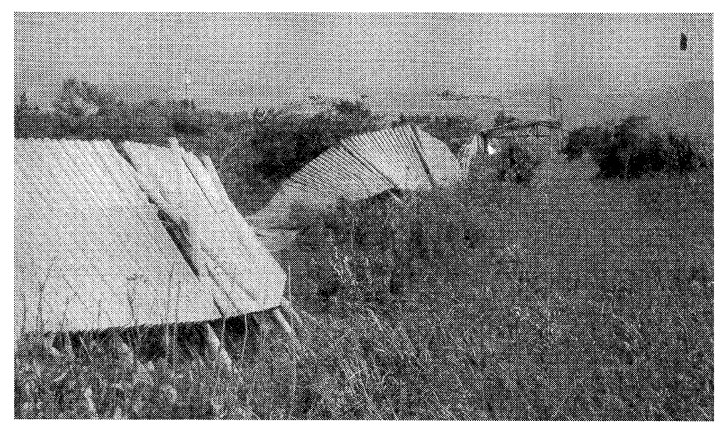

写真 1 緑ヶ丘 5 丁目 海岸における防砂柵の損傷

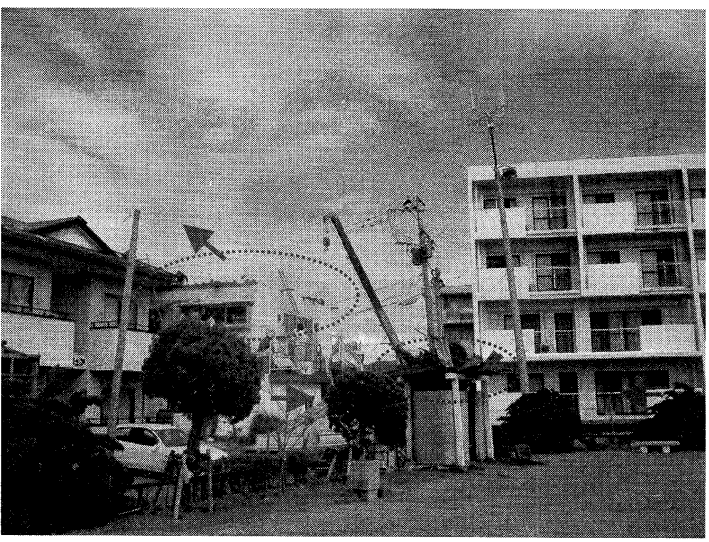

写真 2 緑ヶ丘第一児童公園付近の被害

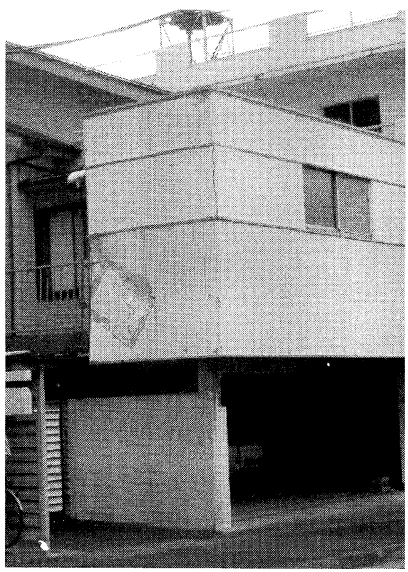

写真 3 緑ヶ丘 4 丁目 と 3 丁目を隔てるバ ス通りに面した建物 の東側壁面に刻まれ たサッシの飛来痕 


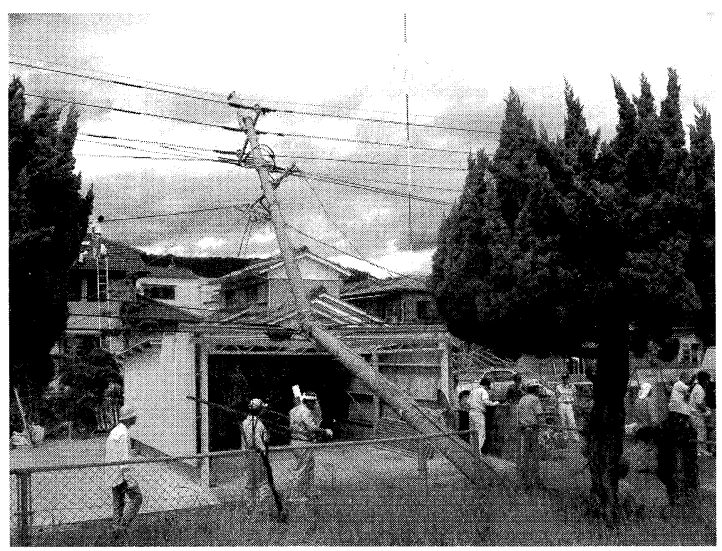

写真 4 緑ヶ丘第三児童公園付近の被害

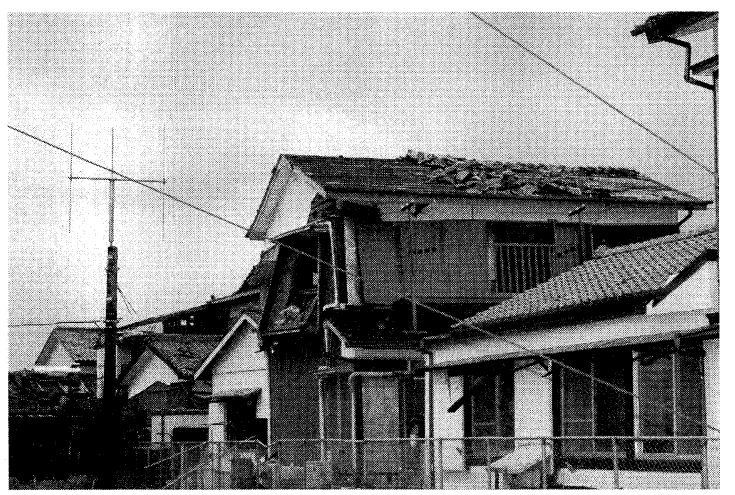

写真 5 竜巻の直撃を受けたと推定される緑ヶ丘の木 造住宅南面（延岡市役所提供，17日撮影）

写真 3 に緑ヶ丘 4 丁目と 3 丁目を隔てるバス通りに 面した建物の被害を示す。外壁にサッシが飛来・衝突 してできた衝撃痕がくっきり残っている。

写真 4 に緑ヶ丘第三児童公園付近の被害を示す。樹 木の被害が激しく周囲の電柱も西に倒壊した。公園内 には多数飛来物が見られた。

写真 5 は被害帯の中央に位置して竜巻の直撃を受け たと推定される木造住宅の一つである。屋根, 空, 外 壁等の目立つ被害に加えて, 柱等の骨組みにも傾斜等 の損傷が見られた。

\section{3 浜町, 別府(びゅう)町, 旭町南部付近の被害}

写真 6 に浜川西側のアパートの被害を示す。切妻屋 根の東側の全てと西側の一部が剥ぎ取られた。屋根の 行方は不明である(付近に落下していないため, 遠くに 飛散した可能性がある)。

写真 7 に国道 10 号沿道の事務所建物の被害を示す。 原型が想像できないほど, 損傷が激しい。

写真 8 に水田の北側の住宅の被害を示す。この付近
では少なくとも 2 件の全壊があった。南側が比較的開 けているが，被害の方向は西向きである。

写真 9 に屋外で高齢者がショック死した浜町の住宅 地付近の様子を示す。周辺の民家の多くで瓦が飛散し, 被害者近くの温室も倒壊したが，被害者に外傷は無か った(宮崎県警)。

写真 10 の大型量販店の店内では, 商品棚が転倒し て高齢者が亡くなった。竜巻通過時の急激な気圧低下 で屋根ふき材折板の一部が剥がされ室内の気圧が下が り, 建物東面の出入口の風除室のサッシが建物内側一 吸い込まれ, 近くの商品棚を転倒させたと推定される。

写真 11 に大型量販店(写真 9)西側のアパートの被害 を示す。南側は空の殆どが被害を受け, 北側は切妻屋 根が剥ぎ取られた。

写真 12 に自動車整備工場の被害を示す。浜川と道 路が並行して東西に走る南側からの飛来物や風圧によ り，屋根，空，外壁等の外装材を中心に大きな被害が 発生している。

写真 13 に運転士と乗客 6 人が軽傷を負った JR日豊 本線「にちりん」の横転と付近の被害を示す。「にちり ん」は先頭車両と 2 両目が西側に横転した。周囲の住

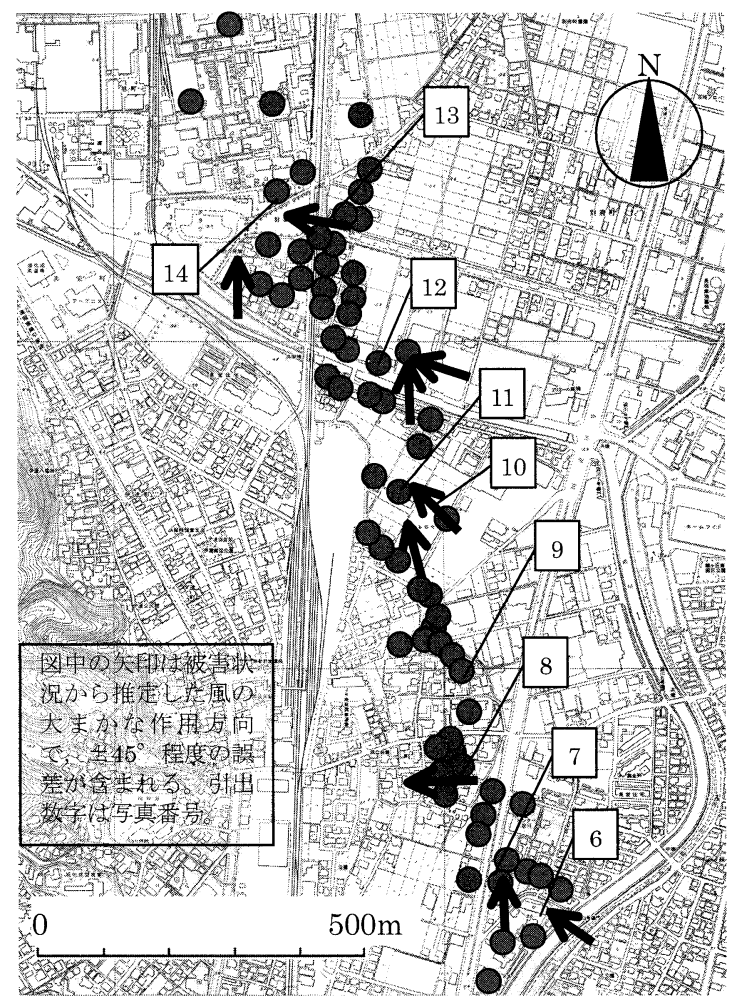

図 7 浜町，別府(びゅう)町，旭町南部付近の被害 


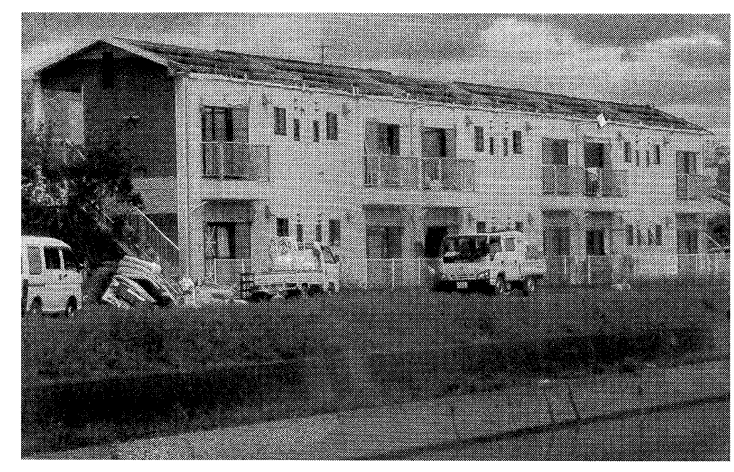

写真 6 浜川付近のアパート東面の被害

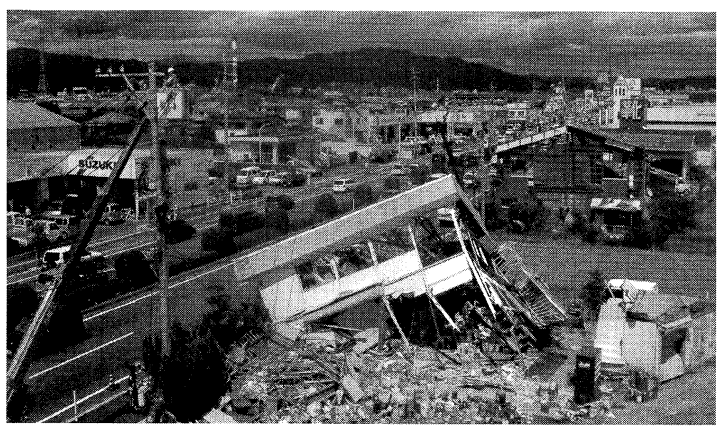

写真 7 国道 10 号バイパス沿道の事務所建物の被害

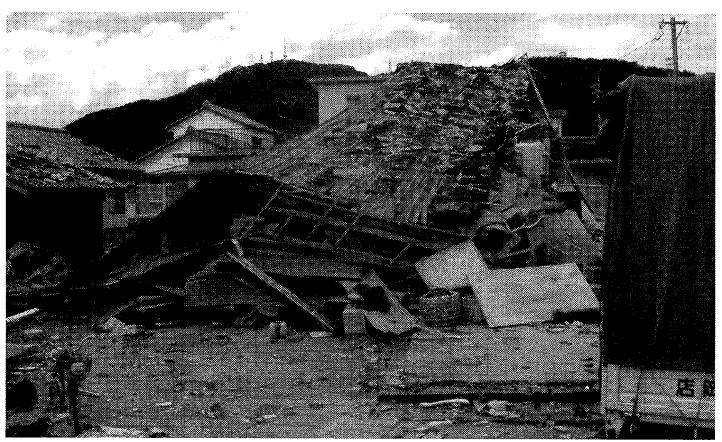

写真 8 浜町における水田の北側に面した住宅の被害

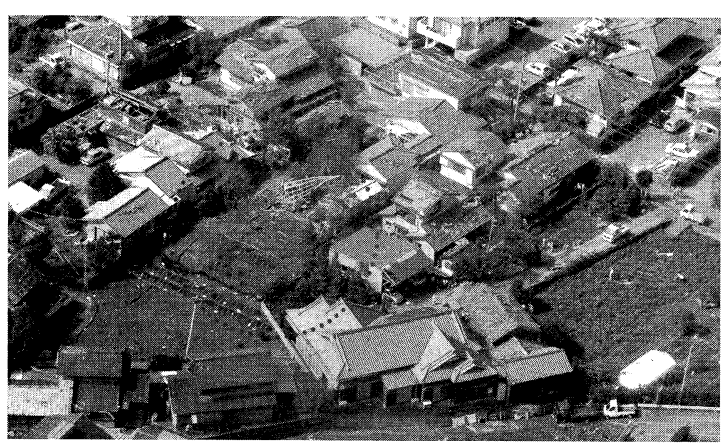

写真 9 丸印付近の屋外で高齢者がショック死した浜 町の住宅地（延岡市提供, 宮崎県防災救急へリ「あお ぞら」から，18 日撮影)

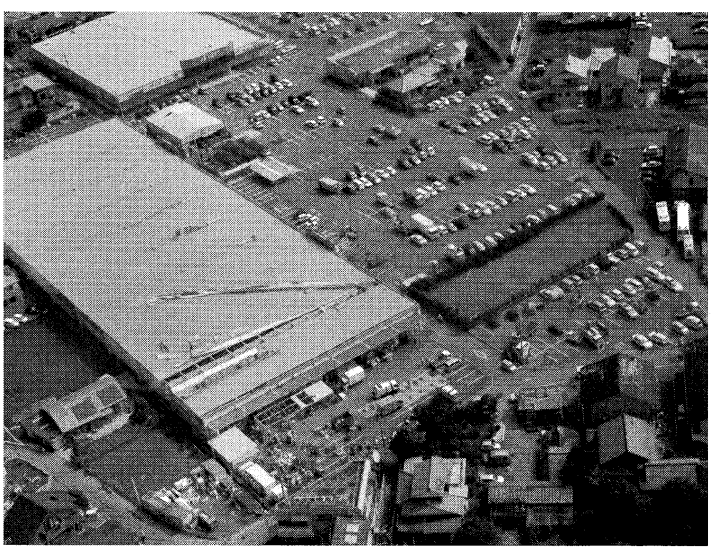

写真 10 入口サッシの倒壊で死亡事故が発生した大型 量販店（延岡市提供，宮崎県防災救急へリ「あおぞら」 から 18 日撮影)

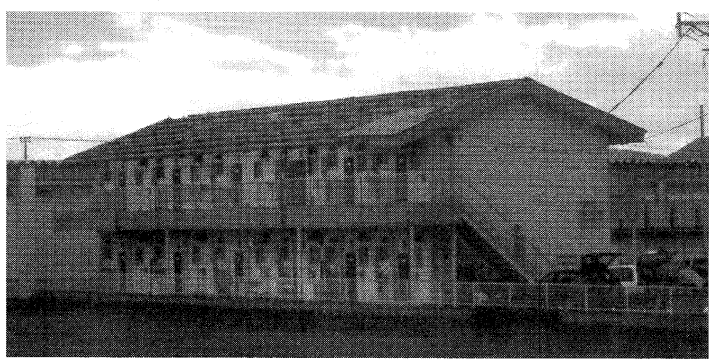

写真 11 大型量販店西側のアパートの被害

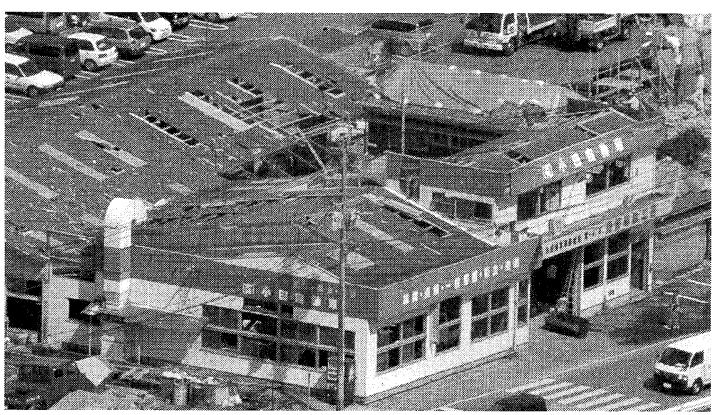

写真 12 自動車整備工場の被害

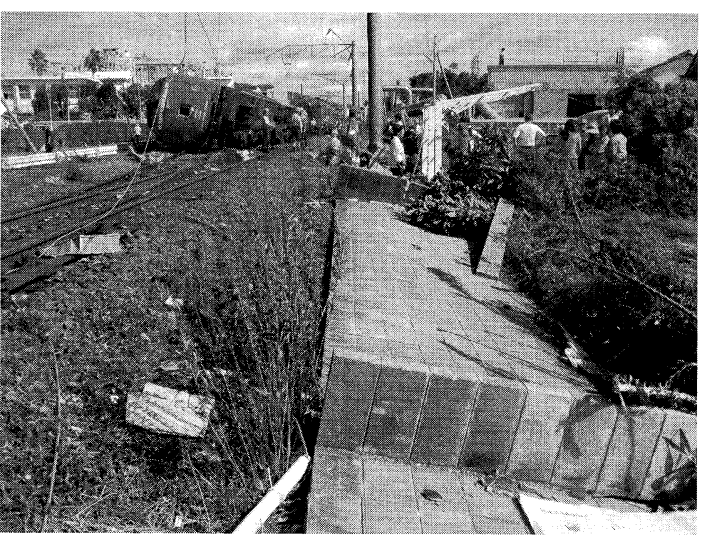

写真 $13 \mathrm{JR}$ 日豊本線「にちりん」の横転と付近の被害 


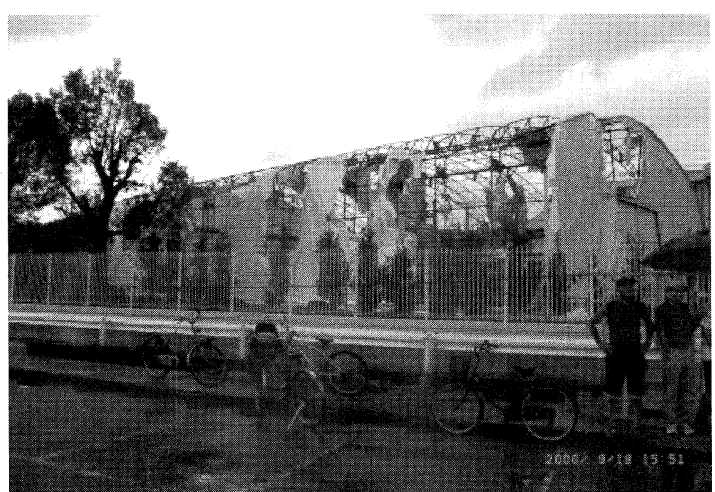

写真 14 テント構造物の被害

家や塀，樹木，電柱にも大きな被害が生じている。い ずれも西ないし北西向きの強い風が作用したことをう かがわせるものである。乗客の一人は，横転の様子を 「ゆっくり倒れ込んだ。と表現している。

写真 14 にテント構造物の被害を示す。「にちりん」 の転覆事故の北西側である。むしりとられた様な皮膜 材の損傷が生じている。

\section{4 旭町, 中島町, 新町付近の被害}

旭町における被害の例を示す。写真 15 に工場外壁 の被害を示す。建物南面, 東面の外壁が破損している。 特に東面には飛散物が衝突したと思われる痕跡が残っ ている。

写真 16 に中島町の住宅の被害を示す。波板スレー 卜が飛散物となって外壁を突き破り室内の扉に突き刺 さった。飛散物の衝撃力が非常に大きいものであるこ とがわかる。また，この住宅に隣接する住宅では写真 17 のように飛散物により外壁に損傷を受け, 屋根の一 部が飛散した。これらの飛散物は，南側工場から発生 したと見られる。

新町では，大瀬川に面した建物の外壁に損傷が顕著

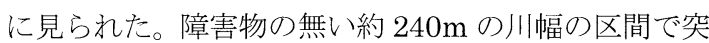
風が強まった様に川に面した部分で被害幅が広がって いる。さらに，この地域は飛散物による被害が顕著で あった。写真 18 は, 南東側の住宅の瓦屋根が飛散物 となり衝突することによる被害である。南面よりも東 面の被害が大きく, 竜巻が反時計方向の回転であるこ とをうかがわせる。

写真 19 は, 屋根の一部(波板トタン)と野地板, 垂木 が飛散し，電線に引っかかった状態になっている。こ の付近には，他の金属板屋根字き材も飛来してきてお り，やはり電線に損傷を与えている。写真 20 は，壁
材に角材が衝突した状況である。2 本の角材がサイデ イングを突き破っている。写真 21 は，鉄筋コンクリ 一ト構造のピロティにおける軒天井の被害である。こ の様に, 構造骨組は無被害な鉄筋コンクリート構造で も，軒天井に被害を受けた建物が散見された。

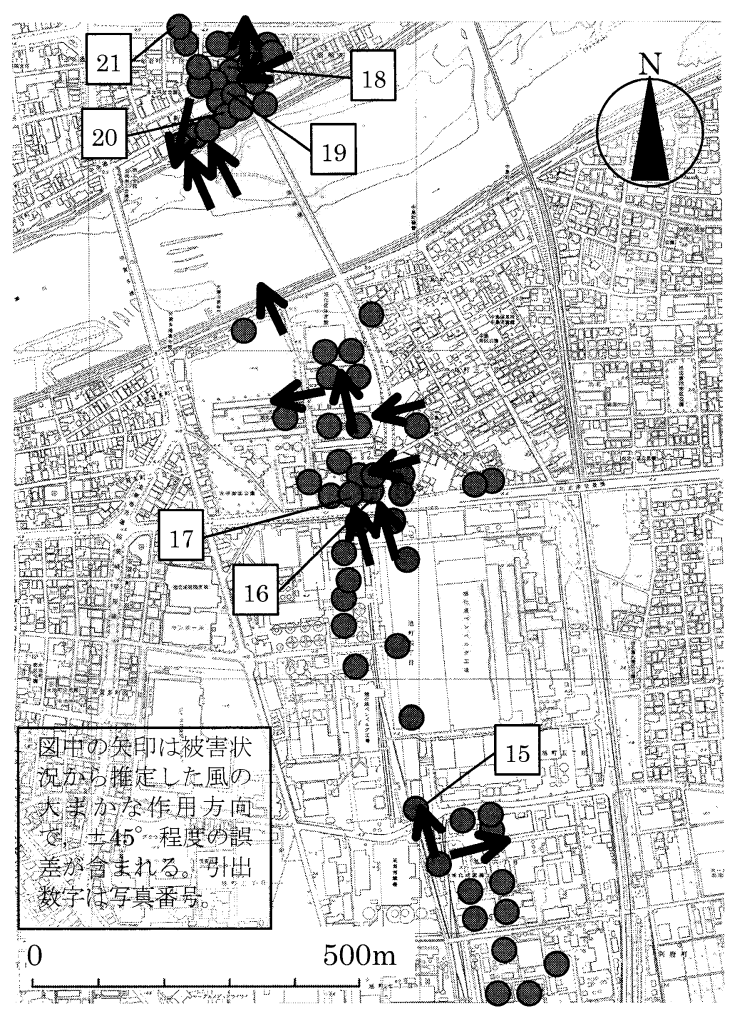

図 8 旭町, 中島町, 新町付近の被害

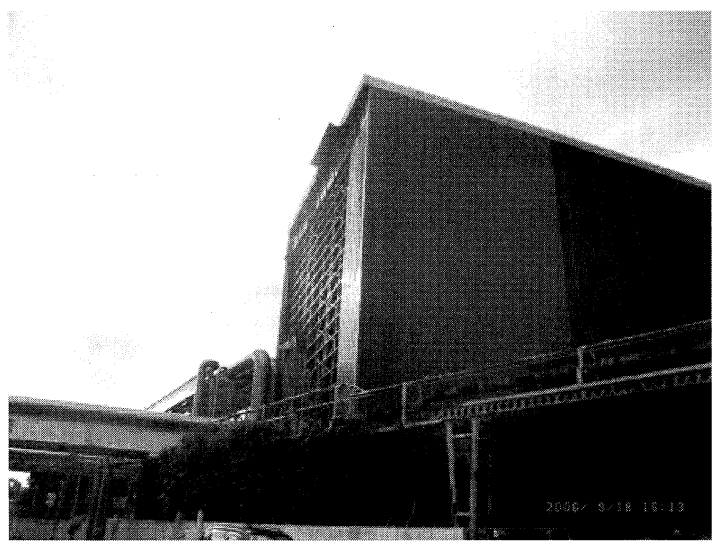

写真 15 工場外壁の被害(南東側から，外壁の剥離) 


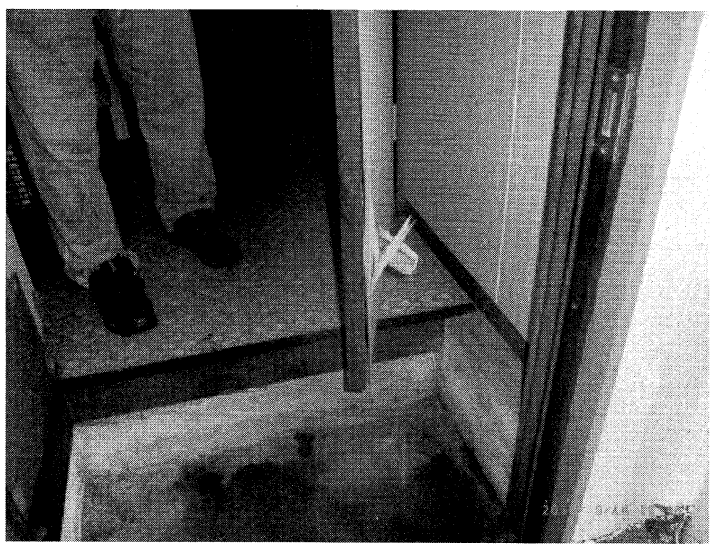

写真 16 飛散物が外壁を突き破って室内の戸に突き刺 さった状態

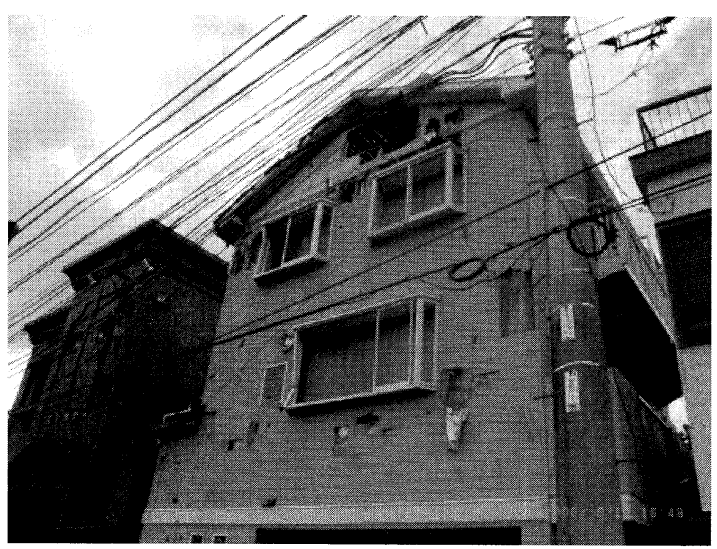

写真 17 飛散物による外壁の損傷

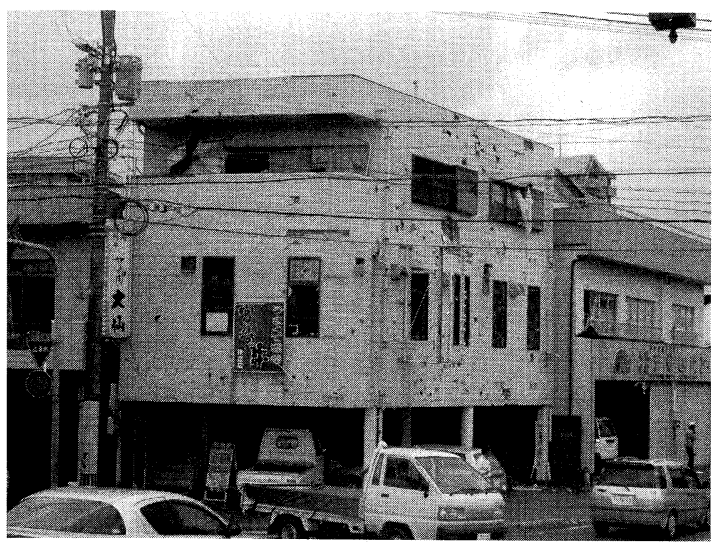

写真 18 飛散物による外壁の損傷（延岡市役所提供, 17 日撮影)

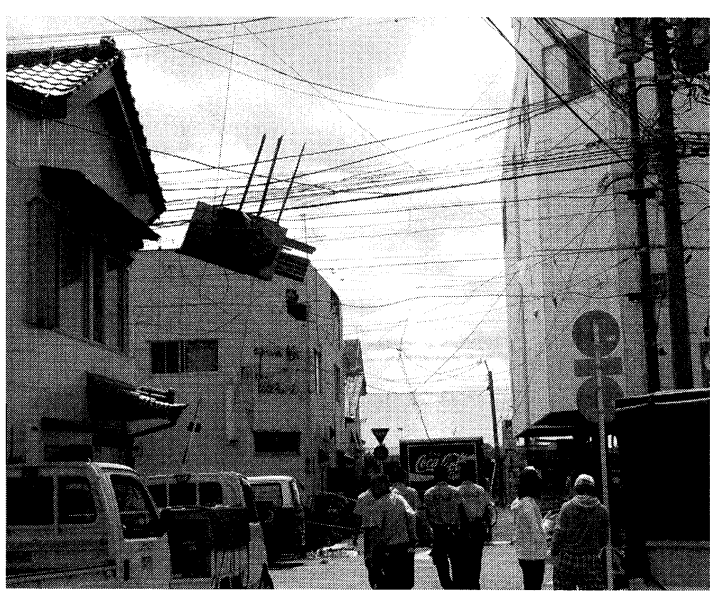

写真 19 飛散物(波板トタン屋根)による電線の被害

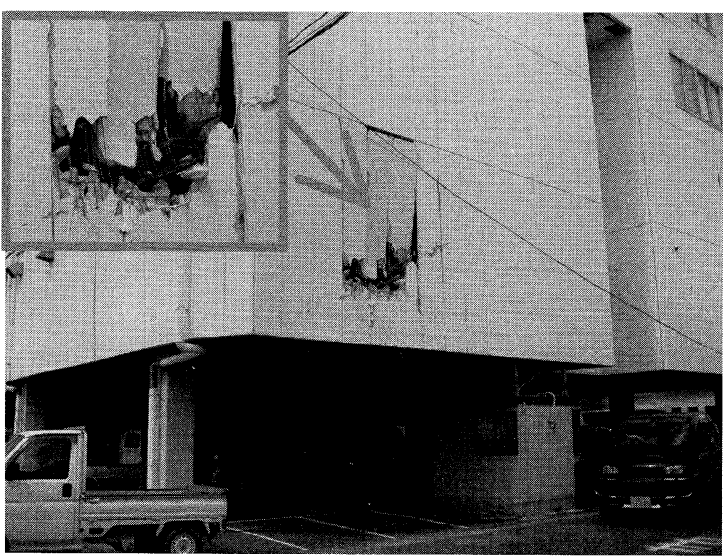

写真 20 飛散物(角材)によるサイディングの被害

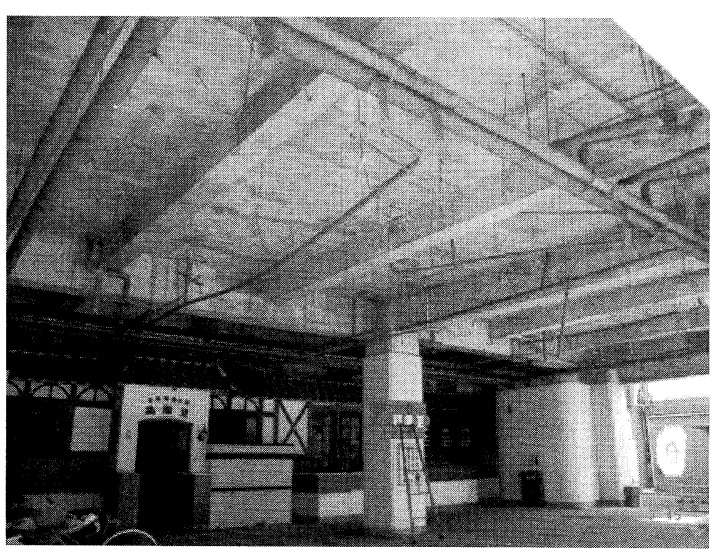

写真 21 鉄筋コンクリート建築物のピロティ軒天井の 被害 


\section{5 船倉町, 紺屋町, 祇園町, 博労町, 栄町, 山下町 付近の被害}

船倉町では，飲食店街の看板が吹き飛ばされた。駐 車場では看板，自動販売機に北から南へ向かって倒壊 しているものが見られた(写真 22)。この駐車場では, 標識等にも被害がでているが，倒壊方向が東向きのも のもあり, 飛散物の衝突などの影響も考えられるが, 非常に複雑な風の力が作用したようである。多くの被 害が，建物東面，南面に集中していたが，五ヶ瀬川沿 いのホテルの北面のガラスに被害が出ていた(写真 23)。

紺屋町では, 五ヶ瀬川沿いのホテルの空ガラスが大 きな被害を受けた(写真 24$)$ 。

博労町では, 高架水槽のタンクの落下があった(写真 $25)$ 。

恵比須町では，写真 26 に示寸ように比較的簡易な 造りの木造建物の被害が見られた。また，店舗でガラ ス面積を広くとっている建物でガラスが殆ど全て破損 した(写真 27)

山下町は住宅街であり，住家に多くの被害が見られ た。また，飛散物によって1名が亡くなった。寝室に 瓦やガラスが散乱しており，雨戸をたてていない空か ら飛来してきたものが頭にあたったものとみられてい る。写真 28 は電柱の折損被害である。電柱は北側に 倒壊した。写真 29 は住宅の外壁の被害である。飛散 物の衝突跡が東面にみられた。写真 30 は木造住宅の 屋根面の被害である。瓦は全て飛散しており, 野地板 まで被害が見られる。庇部分の被害が大きい。

写真 31 に山下町の小高い丘陵傾斜面の東向きの谷 間沿いの被害を示す。被害が顕著であるが，この付近 は風が吹き込んでくる東側に障害物がほとんど無いこ と, 谷筋による縮流効果等が, 被害拡大の理由として 考えられる。

写真 32 は前述の谷間のすぐ北側に開発された住宅 団地の被害である。丘陵頂部付近では，障害物が少な いことや，増速効果により風速が増大した可能性があ り, 比較的築年数が浅い住家屋根が野地板ごと剥離す る被害が見られた。

写真 33 は富美山町における北側に傾斜した地形に 建つ住宅の被害である。植生被害の状況から，竜巻は 写真手前の屋根面に被害を与えながら，正面奥の尾根 筋を通過したと判断される。

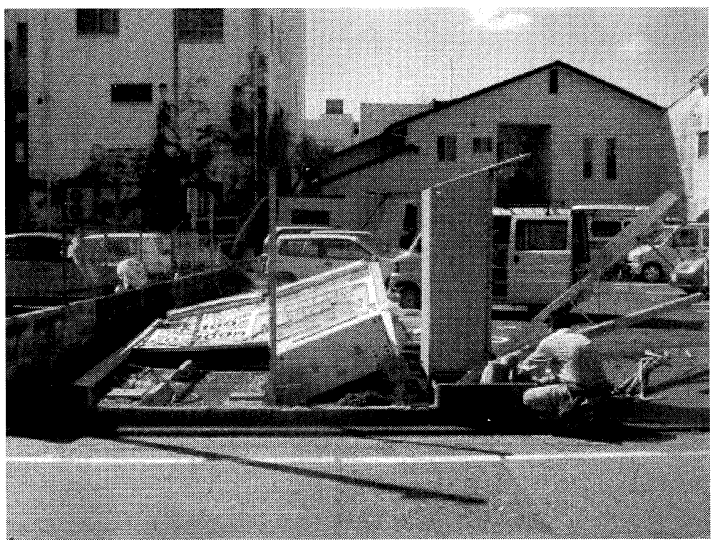

写真 22 船倉町駐車場看板, 自動販売機, 標識の被害

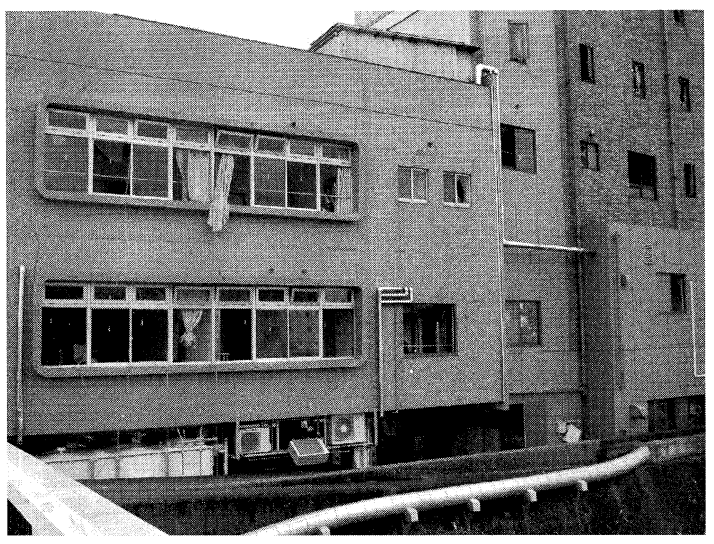

写真 23 船倉町ホテル北面の被害

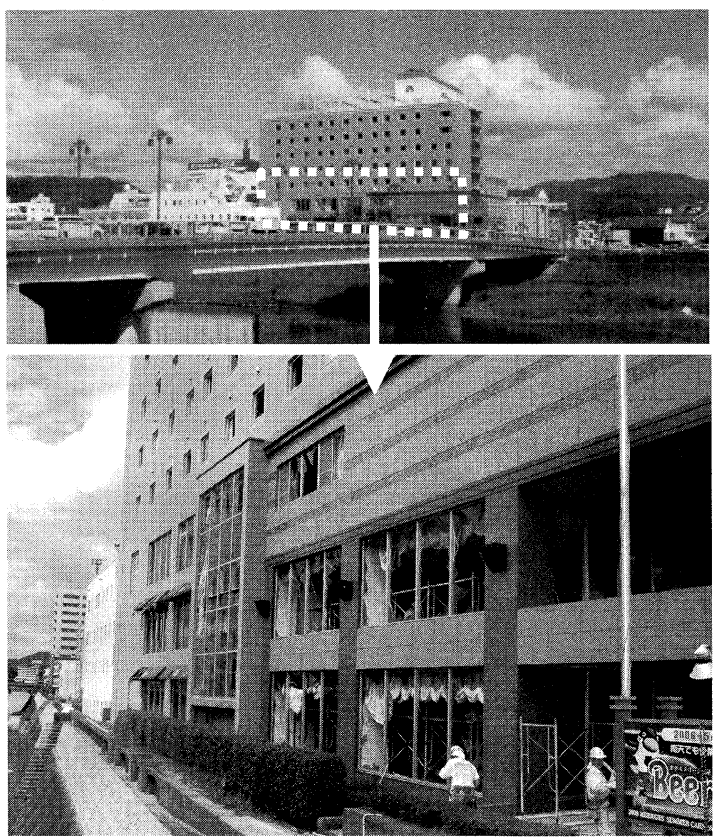

写真 24 紺屋町ホテルの外装材の被害 


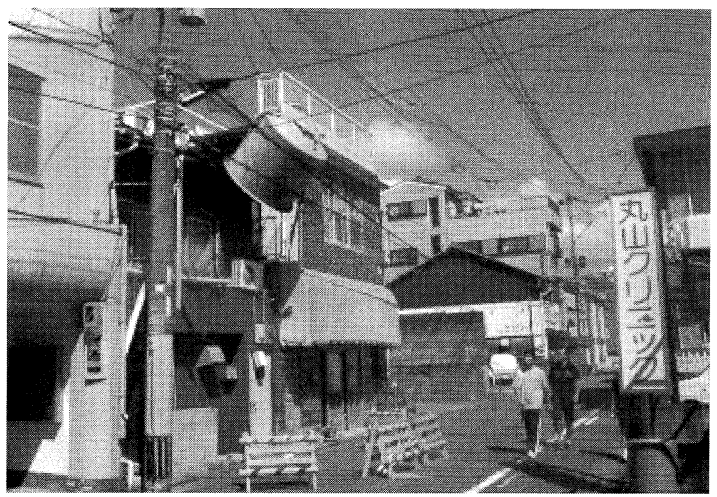

写真 25 博労町の高架水槽タンクの落下

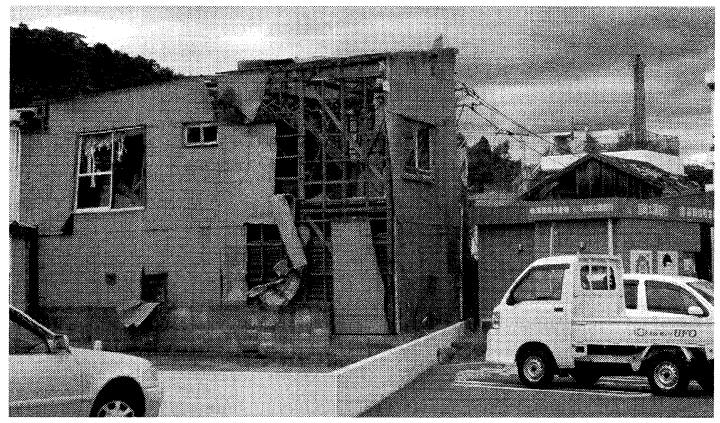

写真 26 恵比須町の木造建物の外装材の被害

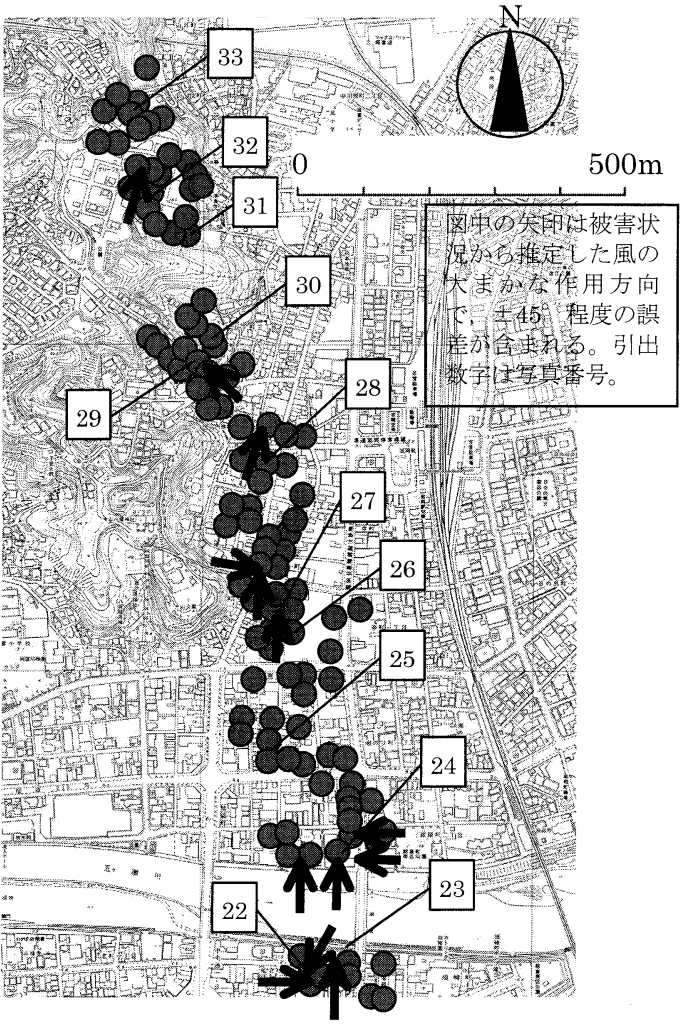

図 9 船倉町, 紺屋町, 祇園町, 博労町, 栄町, 山下町 付近の被害

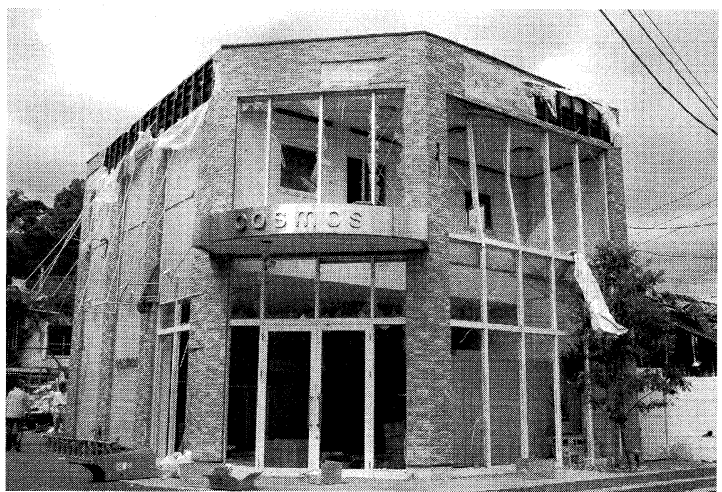

写真 27 恵比須町でみられた外装材の損傷(空ガラス の破壊とサッシの歪み)

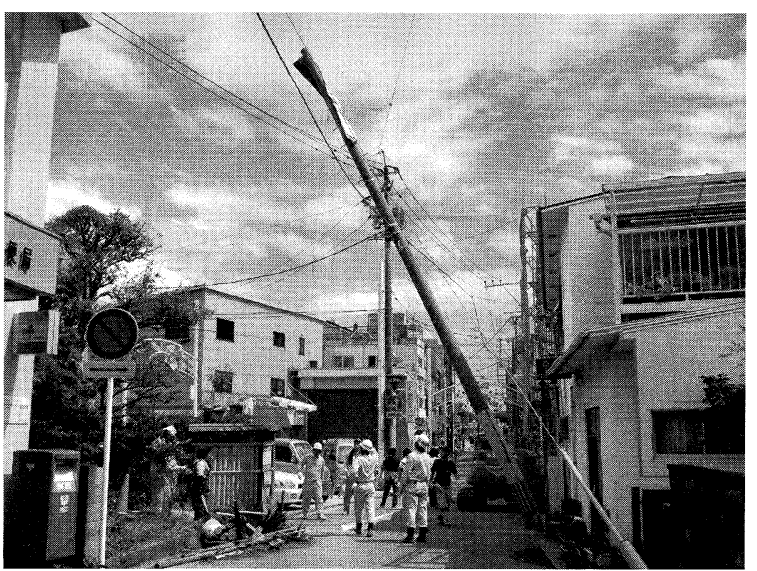

写真 28 山下町の電柱折損

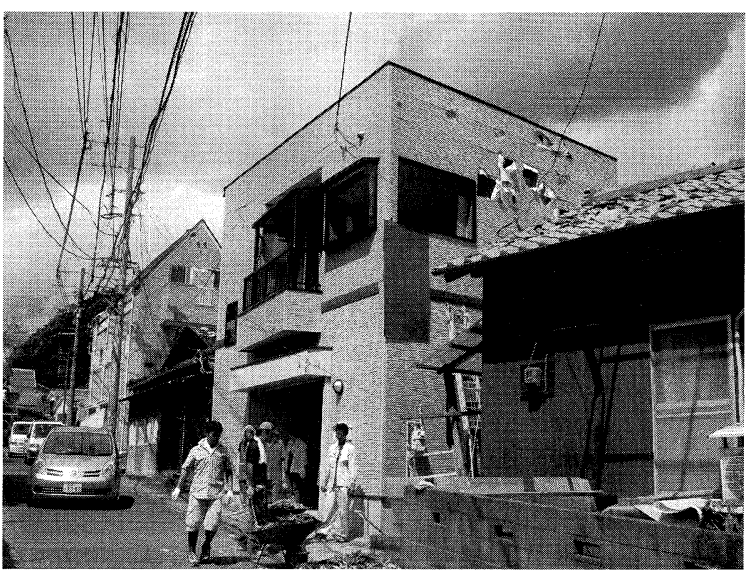

写真 29 山下町の外壁損傷(東面) 


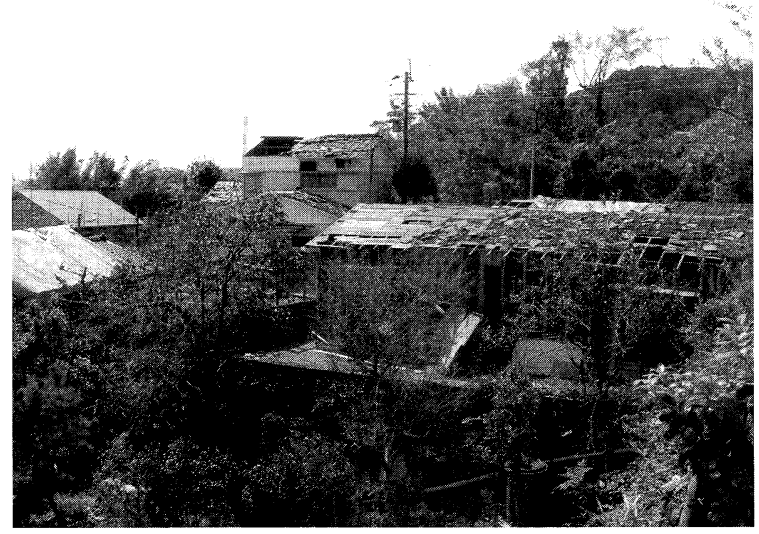

写真 30 山下町でみられた木造住家の屋根ふき材損傷

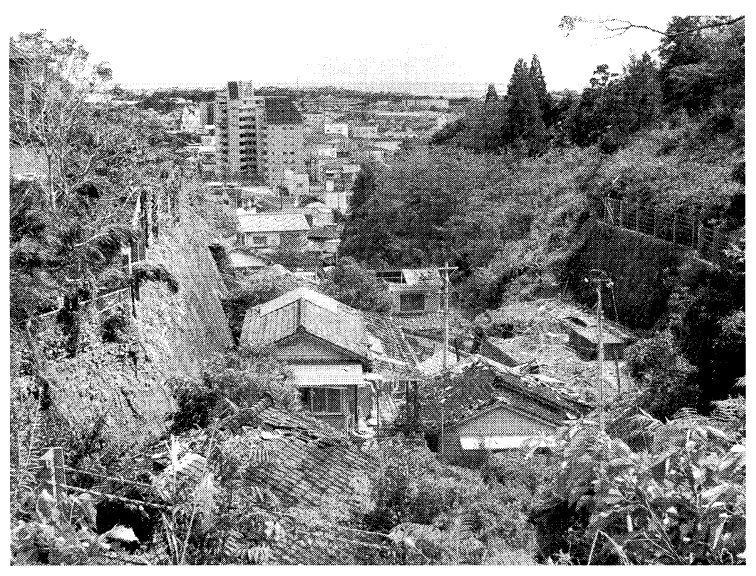

写真 31 山下町における丘陵地斜面の東向きの谷間の 被害

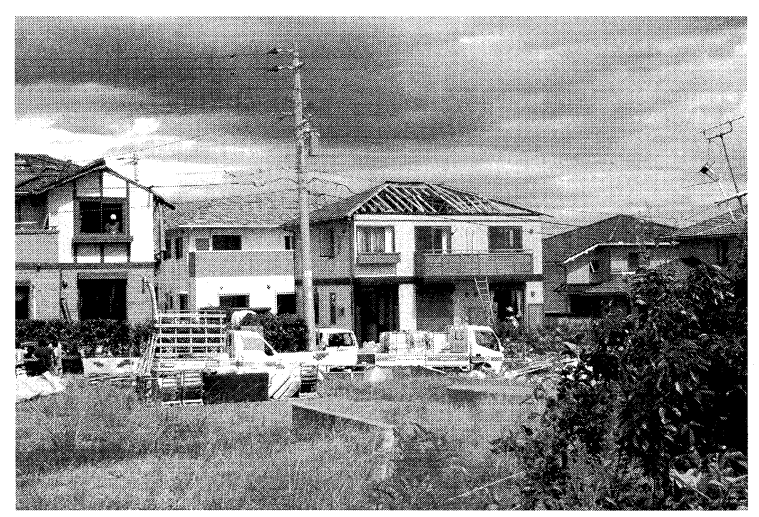

写真 32 丘陵頂部付近における家屋の被害

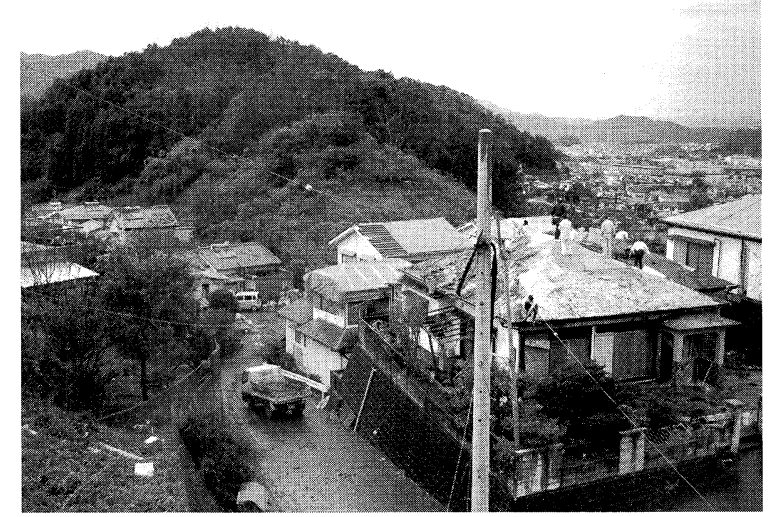

写真 33 富美山町の北側斜面における建物の被害

\section{6 富美山町, 山月町, 中川原町, 尾崎町付近の被害}

写真 34 に示寸富美山町の山田団地付近では, 屋根 に比較的軽微な被害が発生するにとどまった。この付 近では「空からばらばらと物が降ってきた」という証 言も得られた。この付近は地形の起伏が激しく，竜巻 に影響を与えた可能性がある。

写真 35 に中川原町の工場における仮設足場の被害 を示す。ここでは建物の解体工事が行われており，そ の足場が倒壊し，一部が飛散した。写真 36 は，その 飛散した足場の一部が衝突してできたと思われるフェ ンスの被害である。また写真 37 は，飛散した足場が 祝子川（ほうりがわ）を越え, 対岸約 $200 \mathrm{~m}$ の住家を 直撃した被害である。足場板が受風面積を増加させた た可能性がある。横幅 5 スパン $9 \mathrm{~m}$ ，高さ 3 ないし 4 段の $5 \sim 6 \mathrm{~m}$ 程度の大きさで, 今回確認された飛散物 の中では，最大級の大きさである。

尾崎町における稲の倒伏状況をみると転倒方向が 徐々に変化しており，渦を巻いているようにも見るこ とができる。

尾崎町の建物被害は，写真 38 に示すように，水田 地帯を望む北側の山際の集落で発生した。非住家 5 棟 を含む 22 棟の被害のうち 4 割に相当する 9 棟が全壊 となっている。また, 集落内やその南側の水田地帯で は，電柱が多数折損した。

尾崎町の北側は山林になっており, 集落近くに杉の 倒木被害が見られたが，さらに北側の山中に被害が無 いことが空撮（国際航業，9月 21 日）から確認されて おり, 今回の竜巻被害の北端と考えられる。 


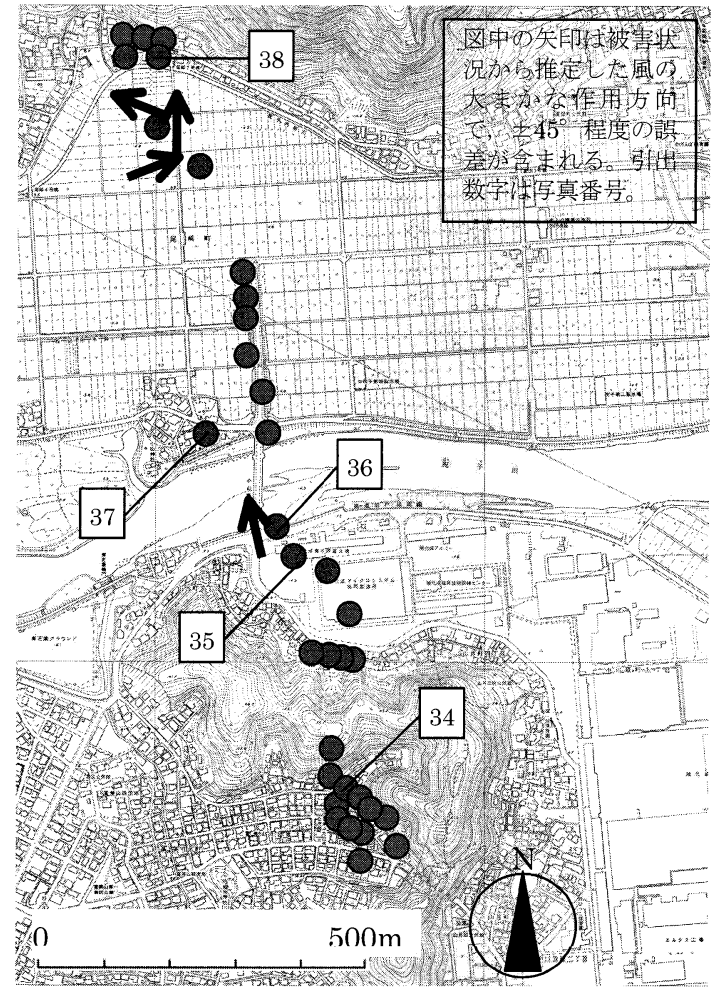

図 10 富美山町, 山月町, 中川原町, 尾崎町付近の被 害

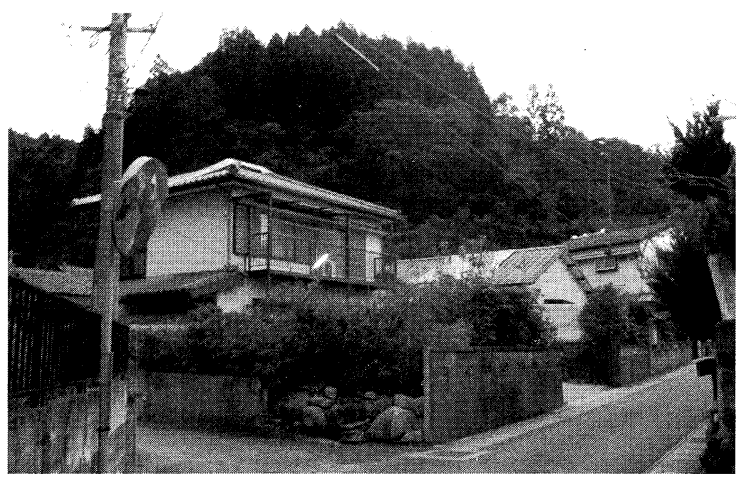

写真 34 富美山町における軽微な屋根被害

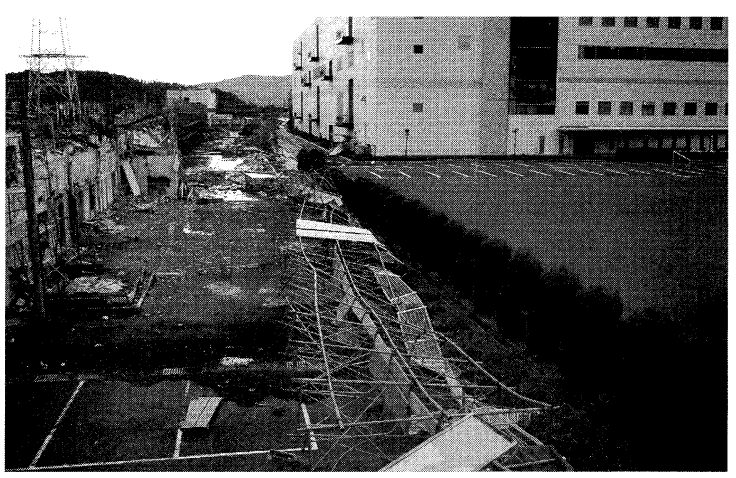

写真 35 中川原町 仮設足場の倒壊

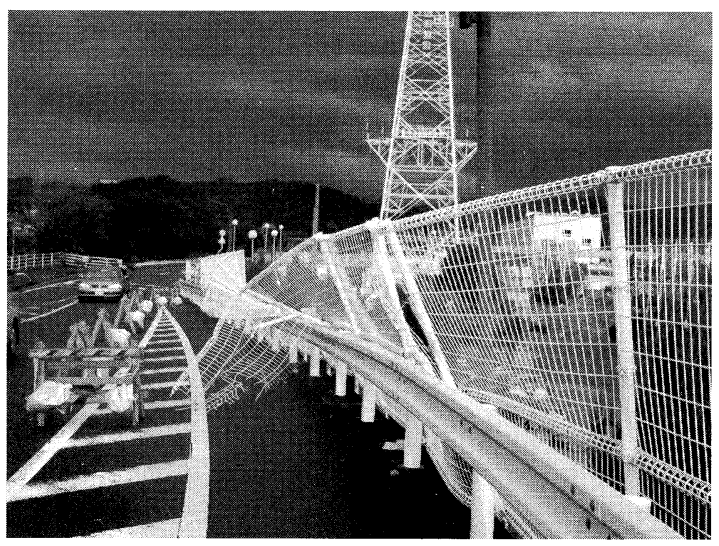

写真 36 中川原町金属網フェンスの被害

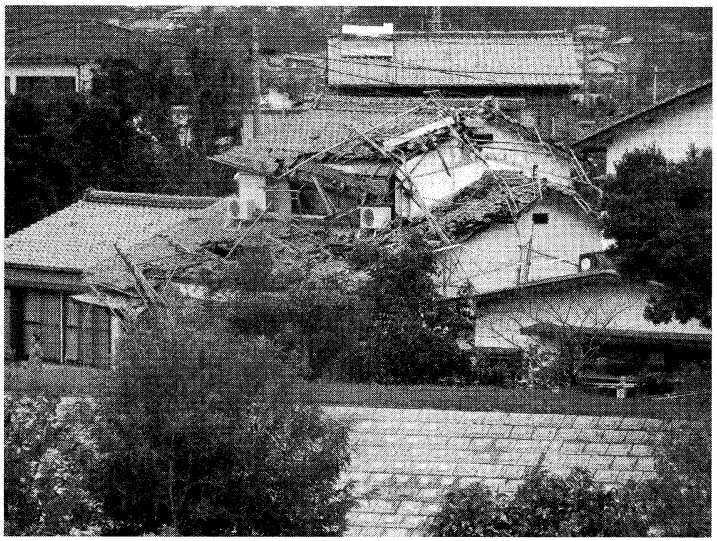

写真 37 祝子川（ほうりがわ）を越えて南東方向約 $200 \mathrm{~m}$ から飛来してきた仮設足場の直撃を受けた建物 (延岡市役所提供，17日撮影）

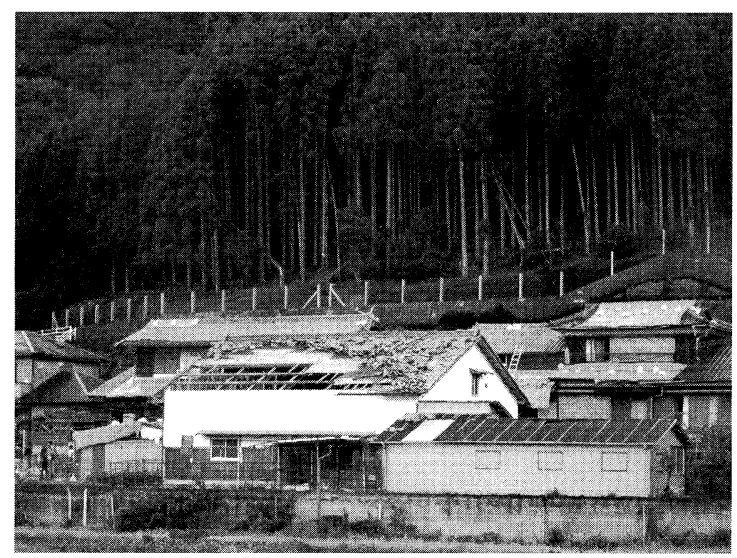

写真 38 尾崎町における住家の屋根被害 


\section{5. 過去の延岡市における竜巻被害}

延岡市は，過去に発生した竜巻について，図 11 の 様に, 大正 4 年 $(9$ 月 8 日午前 7 時, 死傷者 21 名, 半 壊以上 41 棟), 昭和 25 年(7月 19 日, 死者 1 名, 重傷 者 2 名), 平成 5 年(負傷者 1 名, 家屋被害 50 棟), 平 成 15 年(10月 12 日午前 4 時, 半壊 16 棟) と発表して (る 1)。その経路は，ほとんどが海岸から北西に向か っており, 特に昭和 25 年, 平成 15 年の竜巻の経路は, 今回の経路と一部重複する箇所がある。

今回の竜巻発生と同様, 台風時に発生したものもあ り，同様の気象条件での竜巻の発生に注意すべきと考 えられる。

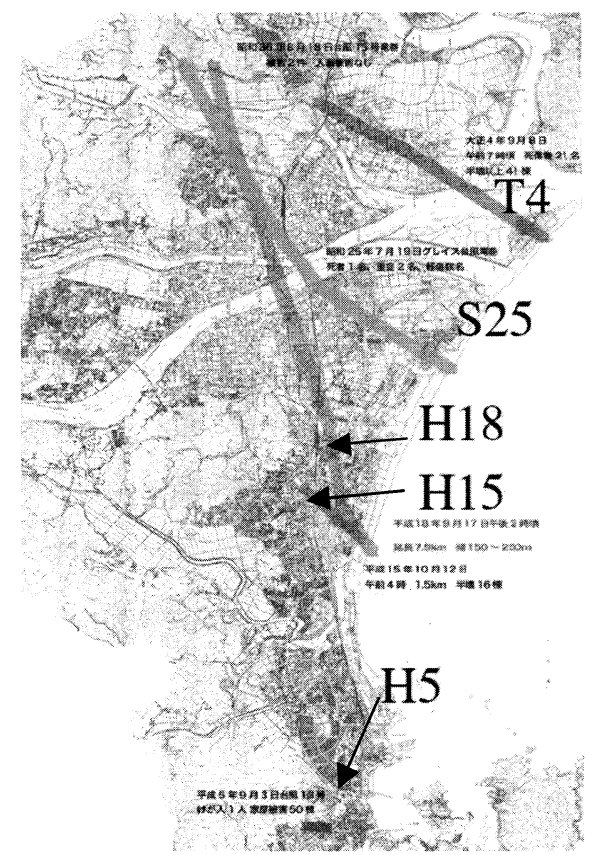

図 11 過去の延岡市における竜巻被害1)(延岡市役所に よる)

\section{6. おわりに}

台風 0613 号に伴って発生した竜巻による延岡市の 突風被害の分布は南北 $7.5 \mathrm{~km}$ 東西 $100 \mathrm{~m} \sim 200 \mathrm{~m}$ で, 極めて局地的に集中したことが特徴であった。

風向，風速などの気象記録は，今回のような局所的 な現象を捉えるには，1 点で計測する風速計では十分 ではないことが，延岡特別地域気象観測所の記録など から明らかとなった。また，竜巻の通過経路にある風 速計が大きな風速を計測しながらも，飛来物による損 傷を受けたことは，竜巻などの気象擾乱に対する風速 計測方法に注意が必要であることを示している。
被害の内容では, 飛散物の発生とそれによる人的被 害，建物一の被害件数が非常に大きかった。飛散物は 建物に被害を与えるとその建物の屋根ふき材が飛散す るきっかけを作り，更なる飛散物を発生させた。飛散 物の衝撃力によりサイディング等を破壊する場合も見 られた。

被害を受けた方向は, 南面, 東面が多かった。この ことは，進行方向が北北西であることを考えると，竜 巻の回転方向が反時計回りであることに対応する。

延岡市役所の調査により過去に同様の経路で竜巻が 発生した記録があることが明らかとなった。

\section{謝辞}

今回の竜巻災害で亡くなられた方の御冥福を心から お祈り申し上げますとともに，被害を受けられた方々 に対してお見舞いを申し上げます。

現地調查に際し, 被災地域の皆椂に貴重な証言を頂 きました。心より謝意を表します。興電社 甲斐稔康様 には初動調査で便宜をはかっていただきました。旭化 成株式会社には風速計の記録をご提供いただきました。 延岡市役所の関係部署，宮崎地方気象台，延岡市消防 本部には，被害情報をご提供いただきました。京都大 学防災研究所 林泰一先生, 丸山 敬先生, 高知大学 佐々浩司先生, 九州大学 前田潤滋先生には貴重なご意 見を頂きました。ここに記して謝意を表します。

地図は国土地理院発行の 2 万 5 千分の 1 地形図，お よび延岡市街地図を利用した。本調査の一部は 21 世 紀 COE プログラム「都市・建築物へのウインド・イ フェクト」, 日本風工学会の突発性災害調査費により行 われた。また追加調査および本報告の作成に当たり

「2006 年台風 13 号に伴う暴風・竜巻・水害の発生機 構解明と対策に関する研究」への科学研究費補助金 (特 別研究促進費）の補助を受けた。

\section{参考文献}

1）延岡市防災推進室，「ぼうさい瓦版」，第 5 号, 2006.11.1 